\title{
PENGEMBANGAN MODEL SIMULASI INTEGRASI BIAYA DAN JADWAL PROYEK KONSTRUKSI DI BAWAH KETIDAKPASTIAN
}

\author{
Deni Setiawan, Ronald Simatupang \\ Dosen Jurusan Teknik Sipil, Fakultas Teknik, Universitas Kristen Maranatha \\ Jalan Prof. drg. Suria Sumantri, MPH., No. 65, Bandung, 40164
}

\begin{abstract}
Construction project has level of higher level risk and uncertainty compared to with manufacture industry. The perpetrators project of construction must be able to assess all changes in weather, material, politics, performance of labour and others as factors considered as risk and uncertainty in decision making. Quantification and minimalizeds risk which caused by postponement in construction industry is a challenge to be developed. Impact losing of float activity non stall is one of postponement which difficult to be assessed either at duration project and also expense of project. This is fact where approach in deterministic, cannot calculate postponement impact of activity non stall. According To CPM, delays activity non stall during doesn't go beyond its(the float total hence doesn't have an effect on to duration of project total. While Ahuja et al ( 1994) exemplifies interesting that delay of activity non-kritis also results contractor to experience financial loss. As a whole, identifies time in accurate figure and prospective in construction industry difficult to be done, even calculates level of risk at level of activity also difficult to be done. This thesis discuss modelling of integration of risk expense and schedule project of construction in simulatif, postponement impact or consumption float activity non-kritis to expense and duration of project total, although the postponement didn't exceed threshold time owned and delay risk of project of construction if(when exalation risk expense of limited and conversely, risk increase of expense of project of construction if(when delay risk of project of limited. Multiple Simulation Analysis Technique ( MSAT) ( Isidore and Back 2002) applied at this thesis for mengenerate expense of project which realible and duration at different value from value losing of float ( time floated) at activity with Monte Carlo technique Simulation (MCS) implementation at (a) Risk applied for men-generate duration and cost. Result of modelling of implication that delaying activity non stall influential to duration of total project of as well as will result the increasing of total cost overall of project.
\end{abstract}

Keyword: MSAT,delay, Simulation Monte Carlo

\begin{abstract}
ABSTRAK
Proyek konstruksi memiliki tingkat risiko dan ketidakpastian yang lebih tinggi dibanding dengan industri manufaktur. Para pelaku proyek konstruksi harus mampu menilai setiap perubahan cuaca, material, politik, kemampuan tenaga kerja dan lain sebagainya sebagai faktor-faktor yang diperhitungkan sebagai risiko dan ketidakpastian dalam pengambilan keputusan. Mengkuantifikasi dan meminimalisasi risiko yang disebabkan oleh penundaan dalam industri konstruksi adalah sebuah tantangan untuk dikembangkan. Dampak kehilangan float aktivitas non kritis adalah salah satu penundaan yang sulit untuk dinilai baik pada durasi proyek maupun biaya proyek. Ini adalah fakta di mana pendekatan secara deterministik tidak dapat menghitung dampak penundaan aktivitas non kritis. Menurut CPM, menunda aktivitas non kritis selama tidak melampaui total float-nya maka tidak berpengaruh terhadap durasi total proyek. Sedangkan Ahuja et al (1994) memberikan contoh yang menarik bahwa keterlambatan aktivitas non-kritis pun mengakibatkan kontraktor mengalami kerugian finansial. Secara keseluruhan, mengidentifikasi waktu secara akurat dan prospektif dalam industri konstruksi sulit dilakukan, bahkan menghitung besarnya risiko pada tingkat aktivitas pun sulit dilakukan. Tesis ini mendiskusikan pemodelan integrasi
\end{abstract}


risiko biaya dan skedul proyek konstruksi secara simulatif, dampak penundaan atau konsumsi float aktivitas non-kritis terhadap biaya dan durasi total proyek, walaupun penundaan tersebut tidak melebihi waktu ambang yang dimiliki serta risiko keterlambatan proyek konstruksi bila risiko ekskalasi biaya dibatasi dan sebaliknya, risiko kenaikan biaya proyek konstruksi bila risiko keterlambatan proyek dibatasi. Multiple Simulation Analysis Technique (MSAT) (Isidore dan Back 2002) digunakan pada tesis ini untuk men-generate biaya proyek yang realible dan durasi pada nilai yang berbeda dari nilai kehilangan float (waktu ambang) pada aktivitas dengan teknik Monte Carlo Simulation (MCS) yang diimplementasikan pada@Risk digunakan untuk mengenerate durasi dan biaya. Hasil pemodelan mengimplikasikan bahwa menunda aktivitas non kritis berpengaruh terhadap durasi total proyek dan juga akan mengakibatkan meningkatnya biaya total keseluruhan proyek.

Kata Kunci: MSAT,Penundaan, Simulasi Monte Carlo

\section{PENDAHULUAN}

Dalam industri konstruksi, manajemen proyek bertujuan untuk menyelesaikan proyek sesuai dengan waktu, biaya serta mutu yang diharapkan. Banyak literatur dan pengalaman empiris menunjukkan bahwa proyek konstruksi senantiasa dihadapkan pada risiko dan ketidakpastian baik internal maupun eksternal, seperti perubahan sistem politik, cuaca, kemampuan dari tenaga kerja, material, peralatan dan pengelolaan. Faktorfaktor tersebut memiliki pengaruh dengan derajat yang beragam terhadap aktivitas konstruksi dan durasi proyek.

Para manajer proyek konstruksi harus bersikap lebih berhati-hati terhadap tingginya biaya dan dampak dari risiko keterlambatan tersebut. Secara keseluruhan, mengidentifikasi waktu secara akurat dan prospektif dalam industri konstruksi sulit dilakukan, bahkan menghitung besarnya risiko pada tingkat aktivitas pun sulit dilakukan. Kekurangan piranti (tools) yang dapat menilai dampak dari keterlambatan dalam proyek konstruksi dapat menambah perselisihan antara owner dan kontraktor.

The critical path method (CPM) atau metoda jalur kritis adalah metoda yang secara luas dan umum digunakan untuk merencanakan dan mengontrol jadual proyek konstruksi. CPM didasarkan pada asumsi bahwa durasi dan biaya dari setiap aktivitas pada jaringan kerja adalah deterministik. Dengan menggunakan metoda ini sejumlah aktivitas yang berpengaruh pada durasi total proyek secara keseluruhan dapat diketahui dan diidentifikasi sebagai aktivitas kritis. Namun, Ahuja et al (1994) memberikan contoh yang menarik bahwa keterlambatan aktivitas non-kritis pun mengakibatkan kontraktor mengalami kerugian finansial. Pengaruh keterlambatan atau penundaan suatu aktivitas nonkritis terhadap durasi dan biaya proyek sulit diidentifikasi melalui pendekatan deterministik yang ada.

Sementara itu, Program Evaluation and Review Technique (PERT) menggunakan pendekatan yang berbeda yaitu stokastik atau probabilistik. PERT menyederhanakan 
permasalahan dengan hanya memperhitungkan jalur kritis hasil perhitungan CPM dalam menentukan risiko keterlambatan proyek. Simplikasi ini menimbulkan problem "mergeevent bias" yang berkonsekuensi risiko keterlambatan proyek menjadi underestimated.(Ahuja et al., 1994, Ang dan Tang, 1982, Ioannou dan Martinez, 1998).

Metoda yang selanjutnya dikemukakan oleh Ang dan Tang adalah Metoda PNET (Probabilistic Network Evaluation Technique). Dalam memperhitungkan risiko durasi proyek PNET hanya mempertimbangkan jalur-jalur yang "representatif". Jalur yang representatif adalah jalur paling dominan yang diseleksi dari satu set jalur yang memiliki satu atau lebih aktivitas sebagai anggota bersama. Sebuah jalur dapat diwakili bila jalur tersebut berkorelasi tinggi dengan jalur yang mewakilinya. Dominasi suatu jalur ditentukan berdasarkan kriteria yang diambil. Ang dan Tang mengambil purata durasi jalur sebagai kriteria, semakin besar semakin tinggi dominasi dan peringkatnya. Jalur yang memiliki purata tertinggi tidak dijamin menjadi jalur yang paling kritis. Sebuah jalur dapat mewakili jalur lainnya bila korelasi antara dua jalur lebih tinggi dari demarcating correlation $\rho_{\mathrm{o}}$, bila tidak, kedua jalur dianggap saling bebas/independen. Perhitungan PNET dilakukan secara manual, maka akan menjadi kompleks jika terdapat jalur aktivitas yang banyak.

Tulisan ini mempresentasikan piranti lunak berbasis Visual Basic Application pada Microsoft Excel yang dapat digunakan untuk menghitung dampak dari tundaan aktivitas non kritis melalui pendekatan simulasi. Piranti lunak yang dikembangkan pada Tulisan ini dimaksudkan agar proses pengintegrasian biaya dan jadwal dapat dilakukan secara otomatis. Melalui piranti lunak ini, diharapkan dapat membantu menghitung penjadualan proyek konstruksi secara otomatis. Untuk proses perhitungan penjadualan, metoda yang digunakan sama seperti pada CPM yaitu perhitungan maju dan mundur serta menghitung durasi Total Float. Proses pengintegrasian biaya dan jadwal dilakukan berdasarkan teori MSAT, serta melalui piranti lunak ini dapat menjawab dampak penundaan aktivitas non-kritis terhadap biaya dan jadwal proyek secara simulasi.

Multiple Simulation Analysis Technique (MSAT) (Isidore dan Back 2002) digunakan pada Tulisan ini untuk men-generate biaya proyek yang realible dan durasi pada nilai yang berbeda dari nilai kehilangan float (waktu ambang) pada aktivitas dengan teknik Monte Carlo Simulation (MCS) yang diimplementasikan pada @Risk digunakan untuk men-generate durasi dan biaya. 


\section{KAJIAN LITERATUR}

\section{Studi Terdahulu tentang Float Aktivitas Nonkritis}

Menurut sejarah, Critical Path Method (CPM) secara luas sudah digunakan untuk perencanaan dan pengendalian pada proyek konstruksi. CPM mengasumsikan bahwa durasi dan biaya dari aktivitas dalam jaringan kerja proyek adalah deterministik. Hal ini berbeda dalam sesungguhnya yang terjadi di dalam pelaksanaan proyek konstruksi. Kenyataannya, setiap aktivitas dalam proyek konstruksi berada pada kondisi ketidakpastian yang meliputi ketergantungan terhadap tenaga kerja, material, peralatan, cuaca dan manajemen. Total Float (TF) adalah salah satu yang dihasilkan dalam perhitungan CPM. Menurut CPM menunda aktivitas non-kritis tanpa melampaui Total Float tidak mempengaruhi durasi dan biaya total dari proyek tersebut. Dilihat karakteristik dari proyek konstruksi yang beresiko dan berada pada banyak kondisi ketidakpastian maka pendekatan deterministik CPM tidak dapat memperhitungkan risiko dan ketidakpastian.

Program Evaluation and Review Technique (PERT) yang dikembangkan oleh Du Pont mengasumsikan secara deterministik. Perhitungan PERT hanya menggunakan ratarata sepanjang jalur kritis. Varians hanya digunakan setelah jalur dihitung untuk menentukan tingkat ketidakpastian yang diasosiasikan dengan rata-rata dari kejadian yang ditentukan. Hasil ini secara keseluruhan dapat dikatakan sebagai "merge event bias" yang membawa kepada perkiraan optimistik dari nilai rata-rata waktu proyek dibandingkan pada rata-rata waktu sesungguhnya.

Diaz dan Hadipriono (1991) menganalisa latar belakang secara teoritis dengan membandingkan PERT, PNET (Probabilistic Network Evaluation Technique), NRB (Narrow Reliability Bounds) dan MCS (Monte Carlo Simulation).

Mengaplikasikan prosedur back forward uncertainty estimation (BFUE), Gong dan Rowings (1995) memperkenalkan konsep penggunaan float yang aman (safe float use) untuk dua aktivitas yang bergabung (merging activities). Menurut Gong dan Rowings, jumlah float yang aman adalah jumlah float yang tidak mengakibatkan perubahan berarti pada ekspektasi durasi total proyek.

Zhong dan Zhang (2003) mengembangkan metoda menghitung float jalur (path float) nonkritis dan merumuskan definisi float jalur yang aman (safe path float). Berbeda dengan Gong dan Rowings yang mendasarkan perhitungan pada ekspektasi durasi proyek, Zhong dan Zhang lebih mentitikberatkan perhitungan dengan tingkat persentil durasi proyek dengan konsep bahwa jalur kritis yang ada tetap dipertahankan. 
Secara umum kesimpulan yang diperoleh dari Gong dan Rowings dan Zhong dan Zhang adalah adanya suatu rentang penundaan yang "aman" untuk aktivitas nonkritis yang tidak berpengaruh secara substansial terhadap durasi proyek. Bila rentang yang aman ini dilanggar atau konsumsi float melebihi batas aman, maka durasi total proyek secara keseluruhan akan terganggu.

Sakka dan El-Sayegh (2007) merumuskan hubungan antara konsumsi float aktivitas nonkritis dan biaya serta durasi total proyek. Dalam studi tersebut mereka menggunakan pendekatan simulasi dengan bantuan piranti lunak @Risk (Palisade Corporation2001).

\section{Definisi dari Integrasi Cost dan Schedule}

Frase "Pengintegrasian Cost-Schedule" mengacu pada preestablished planning structure, digunakan untuk menyediakan informasi yang diperlukan untuk proyek spesifik dalam rangka pengembangan pengendalian estimasi biaya dan jadwal secara probabilitas. Pengendalian estimasi biaya dan jadwal, memberikan baseline pencapaian performance aktual dari sebuah proyek, dan akan diukur selama tahap pelaksanaan proyek. Sistem terintegrasi ini juga akan memberikan pertimbangan bagi pelaku industri konstruksi serta dapat menyediakan informasi yang diperlukan pada proses perencanaan, sehingga dapat memperkecil tingkat risiko pada proyek konstruksi.

\section{Multiple Simulation Analysis Technique (MSAT)}

MSAT (Isidore dan Back, 2002) adalah metoda baru yang dibuat untuk menghubungkan perkiraan biaya proyek (project cost estimate) dengan data jadwal dari rentang estimasi secara simultan dan probabilitas jadwal untuk sebuah proyek. Secara spesifik cara ini dikembangkan untuk mengalokasikan permasalahan keterkaitan antara probabilistik estimasi biaya dengan jadwal proyek pada nilai persentil tinggi yang dipilih untuk kedua tools yang terkait satu dengan yang lainnya.

Teknik ini mengkombinasikan discrete event simulation regretion, dan analisis numerik untuk mengembangkan model yang menjelaskan hubungan keterkaitan antara estimasi biaya stokastik dengan data jadwal. Ketika rentang estimasi dan probabilistik penjadwalan secara independen diaplikasikan pada proyek konstruksi, maka cara ini memberikan lebih banyak lagi rincian dan terintegrasi untuk perencanaan proyek daripada kemungkinan di masa lalu. 
Tahap pertama pada prosedur ini adalah menentukan tingkat persentil yang tetap baik untuk estimasi biaya maupun juga untuk jadwal proyek. Penetapan jadwal proyek maupun estimasi biaya pada predeterminan persentil memberikan analisis untuk proses secara sistematik. Pada kasus biasanya diambil tingkat persentil ke $95 \%$.

Langkah yang berikutnya pensimulasian proyek dan pengurutan data yang hasilnya berdasar pada nilai jadwal proyek. Nilai persentil ke 95\% ditempatkan dan direkam beserta biaya yang sesuai dengan taksiran. Data itu kemudian digunakan untuk menentukan peringkat persentil dari nilai perkiraan biaya, juga direkam. Proyek tersebut disimulasikan kembali 20 kali menggunakan iterasi 500 per simulasi, dan untuk masingmasing simulasi, nilai jadwal proyek pada persentil ke 95, nilai estimasi biayanya yang sesuai, dan peringkat persentil dari nilai perkiraan biaya direkam. Saat data ini direkam, perkiraan biaya rata-rata dan simpangan baku-nya kemudian digunakan untuk menentukan peringkat persentil yang bersyarat dari nilai-nilai estimasi.

\section{PEMODELAN DAN ANALISIS INTEGRASI BIAYA DAN JADWAL}

\section{Studi Kasus}

Proyek konstruksi yang dijadikan sebagai studi kasus untuk penelitian Tesis ini adalah proyek pembangunan jalan bebas hambatan (highway). Proyek ini dibangun sepanjang $11.600 \mathrm{ft}$, diambil dan diadaptasi dari (Brand et al 1964). Tabel 3.1 memperlihatkan nama dari masing-masing aktivitas dengan durasi dan biaya dengan pendekatan tiga nilai mengikuti distribusi beta PERT yaitu optimistic, most likely dan pessimistic. Untuk nilai korelasi antar durasi diberi nilai 0 sampai dengan 1, sedangkan untuk durasi dengan biaya diberi nilai korelasi 0 sampai dengan -1. Biaya indirect cost ditetapkan 500 per hari. Pada Gambar 3.1 memperlihatkan gambar jaringan kerja untuk proyek konstruksi highway. 


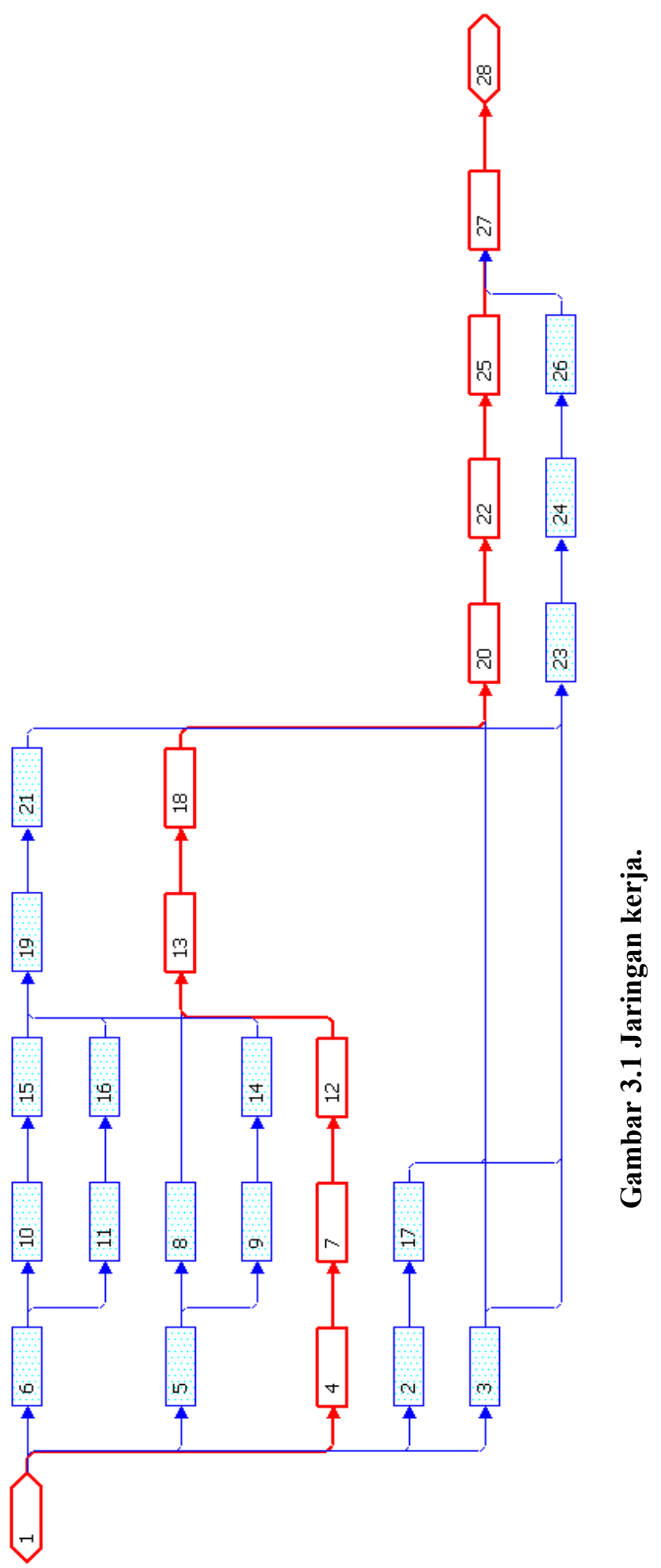




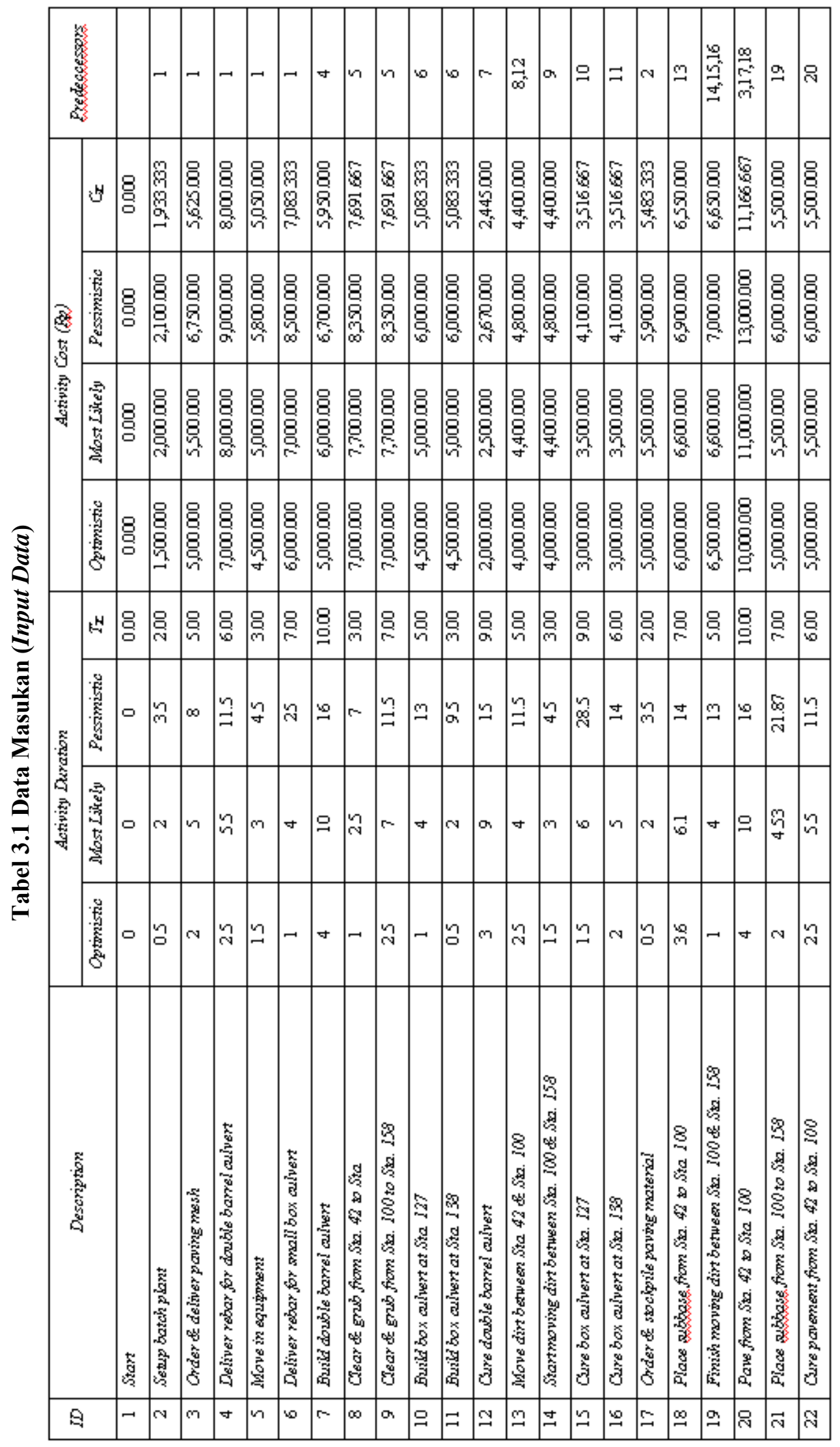




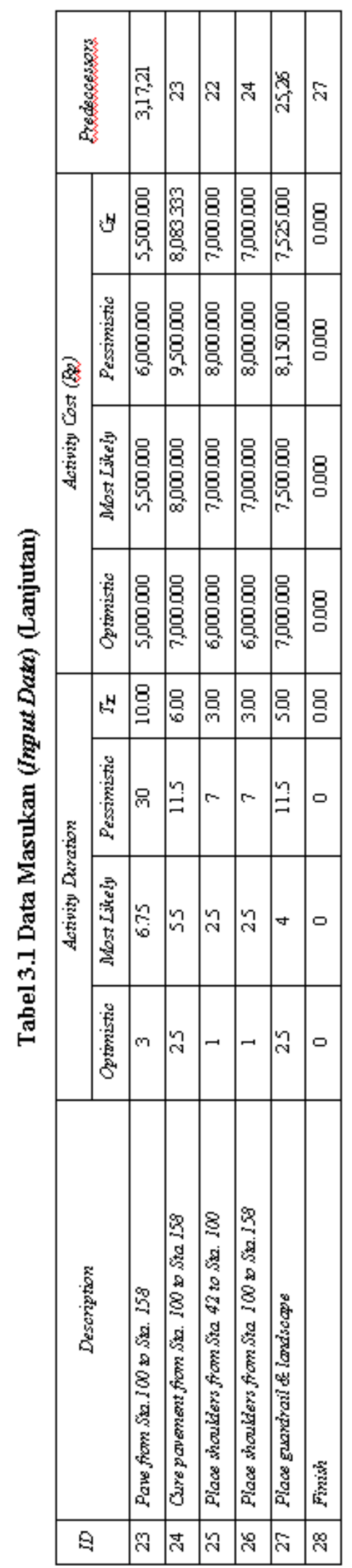

Pengembangan Model Simulasi Integrasi Biaya dan Jadwal Proyek Konstruksi dibawah Ketidakpastian (Deni Setiawan, Ronald Simatupang) 


\section{Perhitungan CPM}

Menurut perhitungan CPM (Critical Path Method), (dapat dilihat pada Tabel 3.2) tanpa adanya penundaan (delay), maka diperoleh jalur kritis pada aktivitas no: 1-4-7-1213-20-22-25-27 dan 28 dengan waktu penyelesaian proyek selama 61 hari dan total cost untuk proyek ini sebesar 183,928.330.

Tabel 3.2 Total Float untuk Seluruh Aktivitas Menurut CPM

\begin{tabular}{|c|c|c|}
\hline ID & Description & $\begin{array}{l}\text { Total Float } \\
\text { (days) }\end{array}$ \\
\hline 1 & Start & 0 \\
\hline 2 & Setup batch plant & 33 \\
\hline 3 & Order \& deliver paving mesh & 32 \\
\hline 4 & Deliver rebar for double barrel culvert & 0 \\
\hline 5 & Move in equipment & 12 \\
\hline 6 & Deliver rebar for small box culvert & 4 \\
\hline 7 & Build double barrel culvert & 0 \\
\hline 8 & Clear \& grub from Sta. 42 to Sta. & 19 \\
\hline 9 & Clear \& grub from Sta. 100 to Sta. 158 & 12 \\
\hline 10 & Build box culvert at Sta. 127 & 4 \\
\hline 11 & Build box culvert at Sta. 138 & 9 \\
\hline 12 & Cure double barrel culvert & 0 \\
\hline 13 & Move dirt between Sta. 42 \& Sta. 100 & 0 \\
\hline 14 & Start moving dirt between Sta. 100 \& Sta. 158 & 12 \\
\hline 15 & Cure box culvert at Sta. 127 & 4 \\
\hline 16 & Cure box culvert at Sta. 138 & 9 \\
\hline 17 & Order \& stockpile paving material & 33 \\
\hline 18 & Place subbase from Sta. 42 to Sta. 100 & 0 \\
\hline 19 & Finish moving dirt between Sta. 100 \& Sta. 158 & 4 \\
\hline 20 & Pave from Sta. 42 to Sta. 100 & 0 \\
\hline 21 & Place subbase from Sta. 100 to Sta. 158 & 4 \\
\hline 22 & Cure pavement from Sta. 42 to Sta. 100 & 0 \\
\hline 23 & Pave from Sta.100 to Sta. 158 & 4 \\
\hline 24 & Cure pavement from Sta. 100 to Sta.158 & 4 \\
\hline 25 & Place shoulders from Sta. 42 to Sta. 100 & 0 \\
\hline 26 & Place shoulders from Sta. 100 to Sta.158 & 4 \\
\hline 27 & Place guardrail \& landscape & 0 \\
\hline 28 & Finish & 0 \\
\hline
\end{tabular}


Berdasarkan nilai total float menurut hasil perhitungan CPM tanpa adanya tundaan, maka dapat ditentukan selanjutnya untuk mengembangkan skenario penundaan aktivitas non-kritis.

\section{Analisis Stokastik Perkiraan Biaya dan Skedul Secara Tradisional}

Untuk memperlihatkan perbedaan antara perkiraan probabilistik secara tradisional dengan metoda MSAT, maka contoh kasus dianalisis baik dengan cara tradisional maupun dengan mempergunakan MSAT. Proyek disimulasikan sebanyak 500 iterasi. Hasilnya dapat dilihat pada Tabel 3.3.

\section{Tabel 3.3 Perkiraan Biaya dan Skedul Untuk Persentil Tinggi \\ Skedul dan Perkiraan Biaya}

\begin{tabular}{|c|c|c|c|c|c|c|}
\hline $\begin{array}{c}\text { Percentile } \\
\text { Level }\end{array}$ & $\begin{array}{c}\text { Project } \\
\text { Schedule }\end{array}$ & $\begin{array}{c}\text { Corresponding } \\
\text { cost estimate }\end{array}$ & $\begin{array}{c}\text { Cost } \\
\text { estimate } \\
\text { percentile } \\
\text { level }\end{array}$ & $\begin{array}{c}\text { Cost } \\
\text { estimate }\end{array}$ & $\begin{array}{c}\text { Corresponding } \\
\text { project } \\
\text { schedule }\end{array}$ & $\begin{array}{c}\text { Project } \\
\text { schedule } \\
\text { percentile } \\
\text { level }\end{array}$ \\
\hline $80 \%$ & 67.89 & $187,258.594$ & $82.90 \%$ & $186,908.484$ & 63.95 & $56.20 \%$ \\
\hline $85 \%$ & 69.03 & $186,717.125$ & $77.50 \%$ & $187,449.318$ & 64.85 & $64.00 \%$ \\
\hline $90 \%$ & 71.26 & $186,717.125$ & $77.50 \%$ & $188,280.831$ & 68.13 & $81.30 \%$ \\
\hline $95 \%$ & 73.73 & $186,717.125$ & $77.50 \%$ & $189,393.394$ & 64.65 & $62.00 \%$ \\
\hline
\end{tabular}

Dari data yang teridentifikasi, nilai skedul proyek dan perkiraan biaya persentil ke 80, 85, 95 dan ke-95 yang diperlihatkan pada Tabel 4.4 pada kolom dua dan kolom lima, merepresentasikan beberapa nilai persentil tinggi yang dipertimbangkan pada rentang estimasi secara tradisional. Pada saat nilai-nilai ini diidentifikasi, pemilihan nilai yang tepat untuk merepresentasikan perkiraan biaya proyek dan skedul dapat dibuat berdasarkan tingkat risiko sesuai dengan pertimbangan seperti: karakteristik proyek tersebut, informasi-informasi spesifik proyek yang tersedia, pengalaman dan penilaian secara teknis dari perencana.

Satu keterbatasan dari pendekatan non-integrasi dapat dilihat dengan pemilihan nilai tingkat persentil ke 95 untuk skedul proyek misalnya 74,01 hari dan perkiraan biaya sebesar 189,712.022. Saat dimungkinkan nilai kombinasi antara skedul dan perkiraan biaya terjadi selama proyek diberikan dengan sejumlah kondisi set yang sangat spesifik, 
kondisi ini tidaklah mungkin mengharapkannya terjadi secara aktual dan simultan selama eksekusi proyek, terutama untuk proyek-proyek yang dikendalikan biaya atau dikendalikan skedul. Sebagai tambahan, variabilitas di dalam durasi aktivitas dan logika eksekusi dari diagram alir proses mungkin tidak mengizinkan kombinasi tersebut terjadi. kombinasi tersebut terjadi.

Daftar nilai kepercayaan skedul proyek yang tinggi beserta aktualnya masingmasing, dan nilai-nilai generate dari simulasi perkiraan biaya dapat dilihat pada Tabel 3.3. Sebagai catatan nilai-nilai tersebut adalah acak (random), keacakan terasebut dapat dibuktikan dengan contoh sebagai berikut: jika nilai kepercayaan ke 95\% dari skedul proyek adalah 73,73 hari, aktual perkiraan biaya yang berhubungan adalah sebesar $186,717.125$ hanya memberikan nilai tingkat kepercayaan sebesar $62 \%$ dari seluruh nilai biaya.

Dengan pengertian lain, jika tingkat kepercayaan perkiraan biaya yang tinggi kemudian diurutkan beserta hasil simulasi nilai skedul proyek, seperti yang diperlihatkan pada Tabel 4.4, maka diperoleh bahwa hasilnya tidak selalu terhubung pada nilai skedul proyek dengan tingkat kepercayaan yang tinggi. Dengan kata lain, memilih sebuah nilai skedul dengan tingkat kepercayaan tinggi tidak dijamin selalu menghubungkan perkiraan biaya yang sesuai dengan nilai skedul terpilih.

Bertujuan untuk menemukan cara analilik untuk menghubungkan data perkiraan biaya dan skedul proyek dari nilai probabilitas yang rendah yang terjadi dapat dipilih untuk keduanya melalui piranti ini. Dengan kemampuan untuk menghubungkan untuk biaya dan skedul pada sebuah logika dan cara sistematis, akan meniadakan cara cobacoba untuk memilih tingkat keyakinan yang tinggi perkiraan biaya dan skedul proyek selama proses perencanaan. Hal ini akan memberikan keputusan secara aktual yang didasarkan pada kombinasi kemungkinan dari perkiraan biaya dan skedul proyek, sedangkan rentang dari distribusi probabilitas sesungguhnya untuk piranti perencanaan ini dihasilkan dari simulasi Monte Carlo, rentang data aktivitas, dan eksekusi aktivitas. Least-square linear regression adalah pertimbangan pertama yang digunakan sebagai piranti untuk menghubungkan nilai-nilai tersebut.

\section{Aplikasi Least Squares Linear Regression}

Hasil berupa diagram scatter dari nilai probabilistik skedul untuk kasus yang kemudian dihubungkan dengan nilai rentang estimasinya dapat dilihat pada Gambar 4.2. Pada saat data-data tersebut diindikasikan hubungannya sebagai linear, maka data tersebut dapat ditentukan melalui persamaan regresi linear dengan mempergunakan nilai 
PS (Project Schedule) sebagai variabel independen dan nilai CE (Cost Estimate) sebagai varibel dependen. Persamaan tersebut dapat dilihat pada Persamaan 3.1.

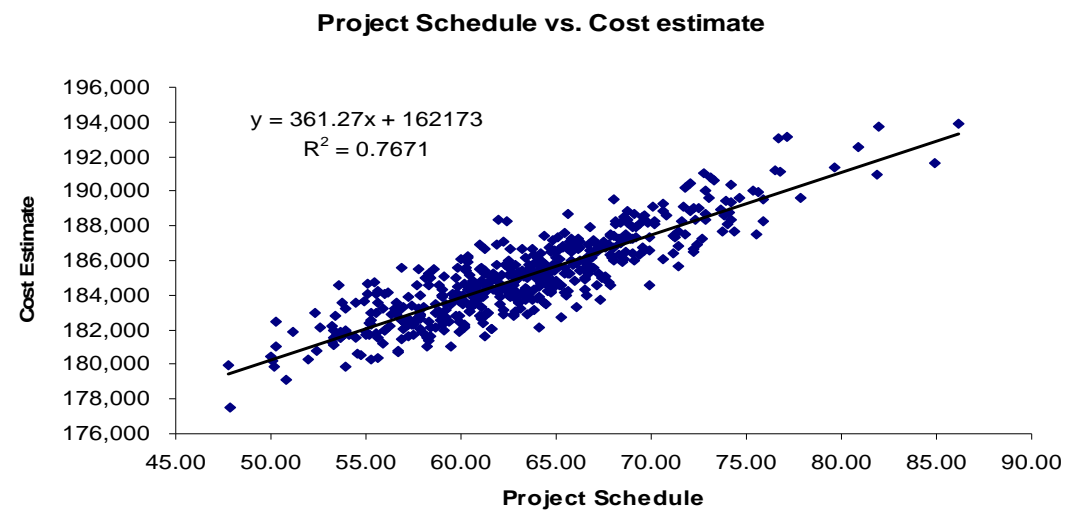

Gambar 3.2 Regresi Linear dari skedul proyek dan perkiraan biaya

Persamaan 3.1 adalah persamaan regresi dari data set berdasarkan minimalisasi leastsquares.

$$
\mathrm{CE}_{\mathrm{i}}=361,27 \mathrm{PS}_{\mathrm{i}}+162173
$$

Dengan nilai koefisien determinasi $\mathrm{R}^{2}=0,7671$ berarti bahwa berdasarkan hubungan regresi linear, skedul proyek mendekati $76,71 \%$ dari variabilitas data perkiraan biaya yang diobservasi.

Bertujuan untuk menghubungkan skedul proyek kepada perkiraan biaya, ada beberapa situasi dimana akan menjadi penting untuk dipertimbangkan dalam menghubungkan perkiraan biaya kepada skedul proyek. Dengan pertimbangan sebagai situasi, maka hubungan regresi linear disesuaikan dengan data perkiraan biaya sebagai variabel penjelas dan data skedul proyek sebagai variabel dependen. Hasilnya menghasilkan persamaan regresi linear yang baru dan berbeda dengan Persamaan 3.1. Persamaan regresi linear-nya diperlihatkan secara grafis pada Gambar 3.3. 


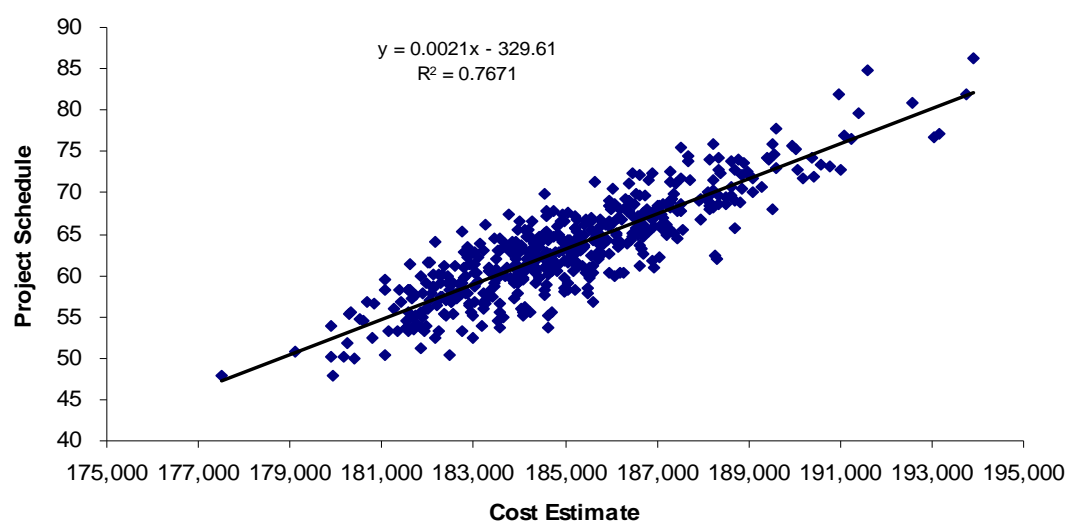

Gambar 3.3 Regresi Linear dari perkiraan biaya dan skedul proyek

$\mathrm{PS}_{\mathrm{i}}=0,0021 \mathrm{CE}_{\mathrm{i}}+329,61$

Koefisian determinasi yang diperoleh dari data melalui persamaan regresi linear adalah sebesar $76,71 \%$ dari variabilitas data yang diobservasi. Dengan demikian dapat disimpulan bahwa baik pada Persamaan 4.1 maupun Persamaan 4.2 mengkasilkan nilai koefisien determinasi sebesar 76,71 \% ini mengindikasikan bahwa data-data yang dihasil pemodelan tradisional belum memberikan nilai koefisien determinasi yang besar dari variabilitas data.

\section{Kesimpulan Pengaplikasian Regresi Linear pada Data Simulasi}

Persamaan 3.1 dan Persamaan 3.2 digunakan untuk memprediksi nilai untuk skedul proyek dan perkiraan biaya pada persentil ke 80, 85, 90 dan ke 95. Hasil perhitungannya dapat dilihat pada Tabel 3.4 dan Tabel 3.5.

Tabel 3.4 Prediksi Interval 95\% untuk Nilai Prediksi Perkiaraan Biaya

\begin{tabular}{|c|c|c|c|c|}
\hline $\begin{array}{c}\text { Percentile } \\
\text { Level }\end{array}$ & $\begin{array}{c}\text { Project } \\
\text { Schedule }\end{array}$ & CE Predicted & CE Lower 95\% & CE Upper 95\% \\
\hline $80 \%$ & 67.89 & $186,741.130$ & $186,608.500$ & $186,873.700$ \\
\hline $85 \%$ & 69.03 & $187,153.290$ & $186,996.500$ & $187,310.100$ \\
\hline $90 \%$ & 71.26 & $187,962.590$ & $187,755.300$ & $188,169.800$ \\
\hline $95 \%$ & 73.73 & $188,856.880$ & $188,591.700$ & $189,122.000$ \\
\hline
\end{tabular}


Tabel 3.5 Prediksi Interval 95\% untuk Nilai Prediksi Skedul Proyek

\begin{tabular}{|c|c|c|c|c|}
\hline $\begin{array}{c}\text { Percentile } \\
\text { Level }\end{array}$ & $\begin{array}{c}\text { Cost } \\
\text { Estimate }\end{array}$ & PS Predicted & PS Lower 95\% & PS Upper 95\% \\
\hline $80 \%$ & $186,879.903$ & 67.40 & 56.57 & 78.22 \\
\hline $85 \%$ & $187,421.063$ & 68.55 & 57.66 & 79.44 \\
\hline $90 \%$ & $188,169.419$ & 70.33 & 59.33 & 81.32 \\
\hline $95 \%$ & $189,712.022$ & 72.70 & 61.57 & 83.82 \\
\hline
\end{tabular}

Berdasarkan hasil pada Tabel 3.4 dapat diinterpretasikan ke dalam "dengan keyakinan sebesar 95\%, purata nilai perkiraan biaya diprediksi berdasarkan pada respektif skedul proyek, terletak di manapun antara nilai prediksi di bawah 95\% dan di atas 95\%”. Interpretasi yang sama untuk nilai skedul proyek pada Tabel 3.5 adalah sebagai berikut "dengan keyakinan sebesar 95\%, purata nilai skedul proyek diprediksi berdasarkan pada respektif perkiraan biaya, terletak di manapun antara nilai prediksi di bawah $95 \%$ dan di atas $95 \% "$.

Berdasarkan hasil observasi dari aplikasi regresi linear, dapat disimpulkan bahwa regresi linear tidak tepat dalam menghubungkan data stokastik untuk skedul proyek kepada perkiraan biaya. Hal ini dikarenakan garis best fit regresi linear tidak dapat menghitung dengan pasti variabilitas dari data output yang dihasilkan oleh pemodelan. Jadi dengan demikian, mencocokan garis regresi pada data nilai persentil tinggi untuk perkiraan biaya menjadi sulit untuk diaplikasikan. Untuk alasan yang sama, akan menjadi sangat sulit untuk menggunakan persentil tinggi dari nilai perkiraan biaya untuk memprediksi nilai skedul proyek dengan persentil yang tinggi. Kesimpulan ini dapat dikonfirmasikan dengan analisa lebar dari interval prediksi untuk nilai estimasi.

\section{Pemodelan Integrasi Biaya dan Waktu Menggunakan Metoda MSAT (Multiple Simulation Analysis Technique)}

Menjawab bagaimana mengintegrasikan jadwal dengan biaya maka hasil pensimulasian pemodelan penjadualan dan biaya proyek dijadikan data masukkan untuk kemudian dilakukan pemodelan dengan metoda MSAT.

Hasil pensimulasian tahap pemodelan penjadualan dan biaya berupa data yang tidak dikondisikan (unconditional). Untuk mengintegrasikan antara jadwal dan biaya maka diperlukan nilai persentil. Hal ini diperlukan untuk melihat bagaimana risiko baik terhadap biaya maupun terhadap jadwal. 


\section{Pengkondisian Biaya (Conditional Cost)}

Tahap pertama dari prosedur perhitungan ini adalah menginputkan tingkat persentil yang ditentukan baik untuk perkiraan biaya maupun jadual proyek. Menentukan jadual proyek dan perkiraan biaya pada persentil yang ditentukan dapat menjadikan proses analisis menjadi sistematis. Pada kasus ini, tingkat persentil dari skedul proyek ditentukan pada nilai persentil 95\% ini berarti kemungkinan cost overrun adalah sebesar $5 \%$. Proyek ini disimulasikan dengan 500 iterasi dan 50 simulasi, hasilnya dapat dilihat pada Gambar 3.4

Project Schedule vs. Conditional Cost Estimate

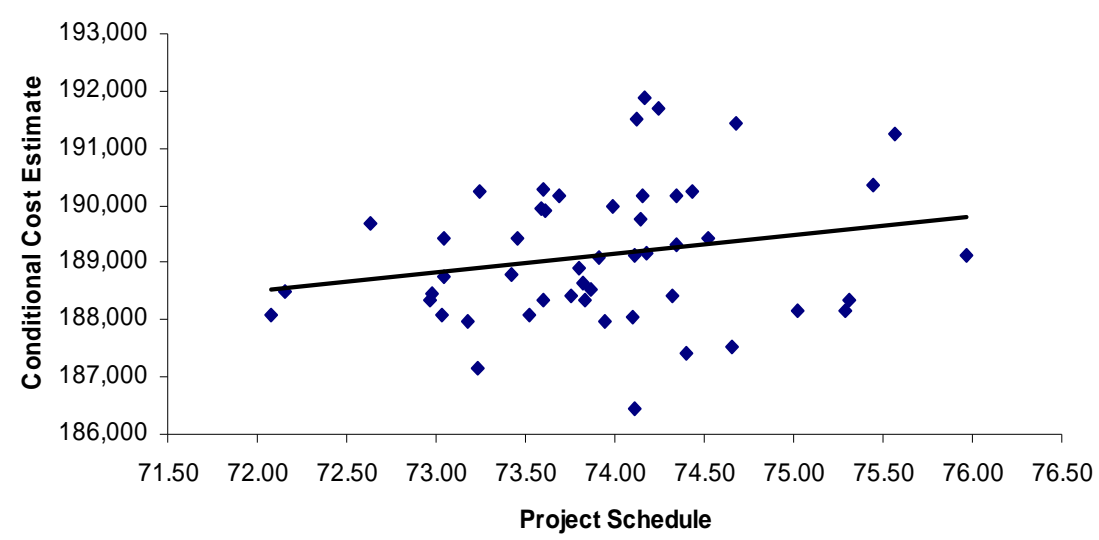

\section{Gambar 3.4 Grafik Hubungan Skedul Proyek dengan Perkiraan Biaya}

Berdasarkan data hasil pensimulasian yang divisualisasikan pada Gambar 3.4 maka dapat dilihat bahwa pada saat diberikan nilai persentil 95\% untuk durasi maka nilai perkiraan biaya setelah dikondisikan berfluktuatif berada pada rentang $188,444.860$ sampai dengan 191,879.590. nilai observasi yang berfluktuatif disebabkan karena nilai acak yang digunakan pada proses simulasi.

\section{Pengkondisian Durasi (Conditional Duration)}

Nilai persentil ke 95 pada nilai perkiraan biaya mengintegrasikan nilai perkiraan biaya dengan perkiraan durasi. Jika nilai persentil 95\% diberikan untuk biaya maka hal ini berarti perkiraan durasi melewati durasi yang diinginkan dibatasi sebesar 5\%. Hasil pengkondisian durasi dapat dilihat pada Gambar 3.5 


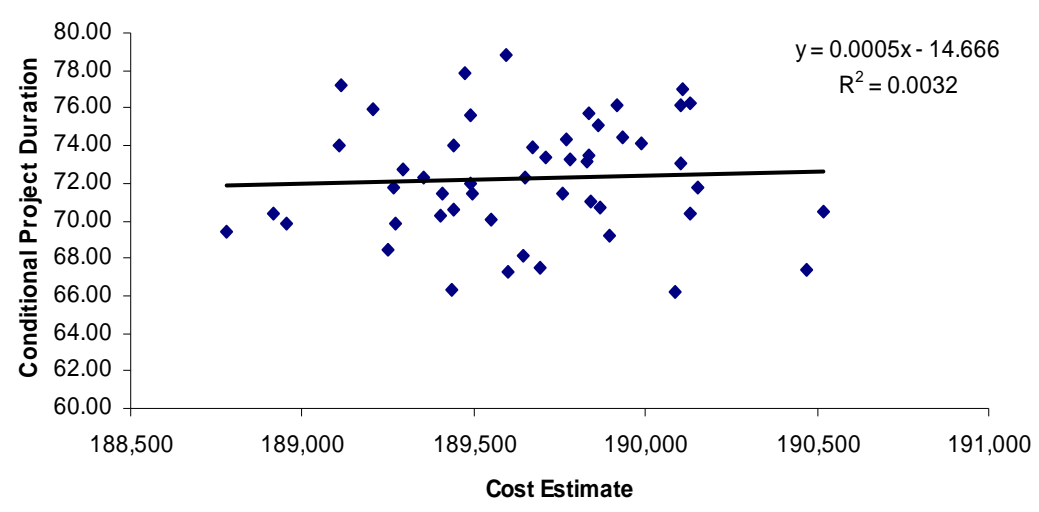

Gambar 3.5 Grafik Hubungan Perkiraan Biaya dengan Skedul Proyek

Berdasarkan data hasil pensimulasian yang divisualisasikan pada Gambar 3.5 maka dapat dilihat bahwa pada saat diberikan nilai persentil 95\% untuk biaya maka nilai skedul proyek setelah dikondisikan berfluktuatif berada pada rentang 66,23 hari sampai dengan 78,87 hari.

\section{Memprediksi Perkiraan Biaya Menggunakan Range Estimate Percentiles.}

Seperti yang telah ditetapkan di awal, nilai perkiraan biaya dipilih pada persentil ke 95 dari skedul proyek. Nilai dari perkiraan biaya ini mewakili proyek secara keseluruhan. Secara menyeluruh berarti bahwa memungkinkan untuk menyelidiki nilai ini secara subset yang terpisah untuk melihat jika menyediakan informasi tambahan yang mengijinkan pemilihan sebuah persentil perkiraan biaya tinggi pada data skedul proyek persentil ke 95. Nilai perkiraan biaya diplot dengan rentang estimasi dan diregresikan. Hasilnya dapat dilihat pada Gambar 4.6 sedangkan persamaan regresi polinomial dapat dilihat pada Persamaan 3.3 


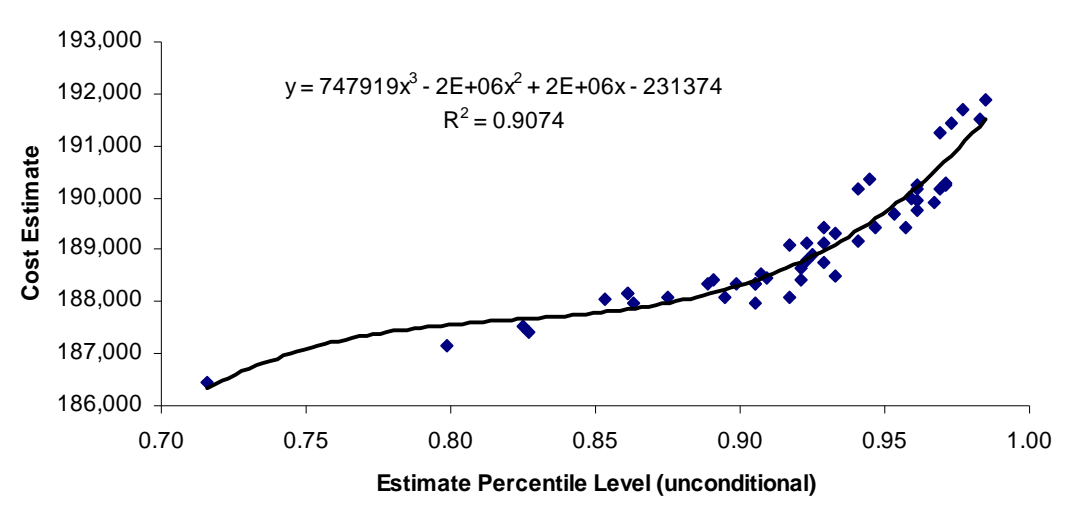

\section{Gambar 3.6 Grafik Perbandingan Nilai Persentil Antara Persentil Range Estimating}

$\mathrm{CE}_{\mathrm{i}}=747919 \mathrm{PL}_{\mathrm{i}}^{3}-2000000 \mathrm{PL}_{\mathrm{i}}^{2}+2000000 \mathrm{PL}_{\mathrm{i}}+23137 ;\left(0 \leq \mathrm{PL}_{\mathrm{i}} \leq 1\right)$

Di mana:

$$
\begin{aligned}
& \mathrm{CE}=\text { Cost Estimate (Perkiraan Biaya) } \\
& \mathrm{PL}=\text { Percentile Level (Tingkat Persentil) }
\end{aligned}
$$

Nilai $\mathrm{R}^{2}=0,9074$ mengindikasikan bahwa penggunaan tingkat persentil unconditional untuk memprediksi perkiraan biaya pada persentil ke 95 skedul proyek dihasilkan pada pendekatan 90,74\% dari variabililtas di dalam perkiraan biaya.

Dari Gambar 3.6 dapat didiskusikan dengan bertambahnya nilai tingkat persentil perkiraan maka akan mengakibatkan bertambahnya nilai perkiraan biaya yang dikondisikan. Dengan bertambahnya tingkat persentil perkiraan maka akan berakibat menurunnya tingkat risikonya, semakin menurun tingkat risiko maka akan mengakibatkan berkurang ketidakpastian biaya proyek tersebut akibat durasi proyek dikondisikan.

\section{Memprediksi Perkiraan Biaya Proyek Menggunakan Conditional Percentiles}

Tahap berikutnya pada proses MSAT adalah menetapkan persamaan regresi pada data perkiraan biaya, men-generete data skedul proyek persentil ke 95 dan persentil pengkondisian dari data tersebut. Hubungan regresi merepresentasikan penetapan pada data. Hubungan regresi ini ditunjukan pada Persamaan 3.4 dan ilustrasinya dapat dilihat pada Gambar 3.7 


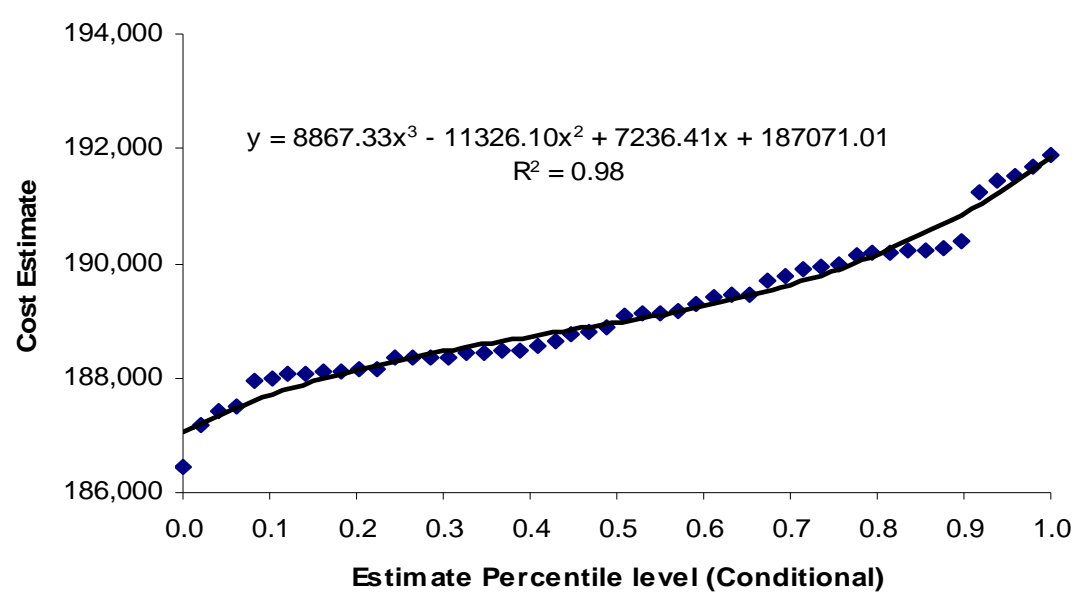

Gambar 3.7 Grafik Perbandingan Nilai Persentil Antara Persentil Conditional Cost Estimate

$\mathrm{CE}_{\mathrm{i} \text { conditional }}=8867,3 \mathrm{PL}_{\mathrm{i}}^{3}-11326 \mathrm{PL}_{\mathrm{i}}^{2}+7236,4 \mathrm{PL}_{\mathrm{i}}+187071$

Di mana:

$\mathrm{CE}_{\mathrm{i} \text { conditional }}=$ Conditional Cost Estimate (Perkiraan Biaya yang dikondisikan)

$\mathrm{PL} \quad=$ Percentile Level (Tingkat Persentil)

Penggunaan range estimating dan conditional percentile level yang kemudian diintegrasikan dengan nilai perkiraan biaya yang di-generate pada persentil ke 95 dari data skedul proyek, memungkinkan untuk dilakukan yaitu dengan menggunakan Persamaan 3.3 dan 3.4 .

Dengan pengintegrasian ini memungkinkan untuk menentukan perkiraan biaya berdasarkan pada tingkat persentil dari skedul proyek. Prosedur perhitungan ini dapat memberikan kemungkinan untuk mempertimbangkan secara cepat berdasarkan pilihan perkiraan biaya melalui seluruh rentang persentil perkiraan biaya, hal ini memberikan tingkat kepercayaan skedul proyek ditentukan pada persentil ke 95.

Hasil pemodelan yang diperlihatkan pada Gambar 3.7 dapat memberikan informasi bahwa jika dibandingkan dengan menggunakan range estimating percentile pendekatan dengan menggunakan conditional percentiles lebih baik karena nilai koefisien determinasi untuk conditional percentile $\mathrm{R}^{2}$ sebesar 0,9751 sedangkan menggunakan range estimating hanya memberikan nilai koefisien determinasi sebesar 0,9074. 


\section{Perbandingan Purata Nilai Perkiraan Biaya}

Uji statistik untuk membandingkan purata pada tingkat persentil ke 80, 85, 90 dan ke 95 untuk nilai perkiraan biaya yang di-generate untuk menghitung secara statistik signifikan atau tidak pebedaan antara nilai-nilai pada Persamaan 4.3 dan Persamaan 4.4. Data ini memperlihatkan purata perkiraan biaya dari pengaplikaian range estimating dan conditional estimating pada tingkat persentil 89, 85, 90 dan 95. Hasil uji statistiknya dapat dilihat pada Tabel 3.6.

Tabel 3.6 Perbandingan Purata Perkiaraan Biaya

\begin{tabular}{|c|c|c|c|c|c|c|}
\hline \multirow{2}{*}{ Percentile ranking } & \multicolumn{2}{|c|}{ Conditional cost estimate } & \multicolumn{2}{|c|}{ Probabilitic Cost } & \multirow{2}{*}{ Sig. } & \multirow{2}{*}{$\begin{array}{c}\text { Statistically } \\
\text { Significant } \\
\text { Difference }\end{array}$} \\
\hline & Cost Estimate & Std. Dev & Cost Estimate & Std. Dev & & \\
\hline 80 & 186767.29 & 1179.08 & 187149.01 & 181.76 & 0.01 & Ya \\
\hline 85 & 187437.08 & 1133.75 & 187684.20 & 201.48 & 0.18 & Tidak \\
\hline 90 & 187756.97 & 1204.32 & 188410.54 & 242.06 & 0.06 & Ya \\
\hline 95 & 189135.14 & 1211.63 & 189651.98 & 381.70 & 0.15 & Tidak \\
\hline
\end{tabular}

Berdasarkan uji perbandingan statistik, secara umum hasil pada kolom 7 mengindikasikan bahwa secara statistik nilai-nilai tersebut signifikan baik untuk range estimating maupun untuk conditional project schedule. Perbandingan signifikan menujukkan bahwa memungkinkan untuk mengaplikasikan prosedur MSAT dengan berdasarkan conditional probability. Bertujuan untuk menghitung harapan nilai persentil perkiraan biaya, pemberian tingkat persentil 95 skedul proyek memberikan keuntungan pada perencana.

\section{Pengembangan Skenario Penundaan Durasi dari Aktivitas Non-Kritis}

Pengembangan skenario penundaan aktivitas non kritis dilakukan untuk menjawab apakah penundaan aktivitas non kritis berpengaruh terhadap durasi total keseluruhan proyek? Pada studi proyek ini, yang ditunda adalah aktivitas deliver rebar for small box culvert. Aktivitas ini akan ditunda berdasarkan perhitungan CPM diperoleh Total Float untuk aktivitas ini adalah empat hari. Lamanya penundaan aktivitas ini ditentukan selama satu sampai dengan empat hari Nilai indeks kekritisan akibat ditundanya aktivitas deliver rebar for small box culvert serta bagaimana hubungannya terhadap aktivitas-aktivitas lain dapat dilihat pada Tabel 3.7. 


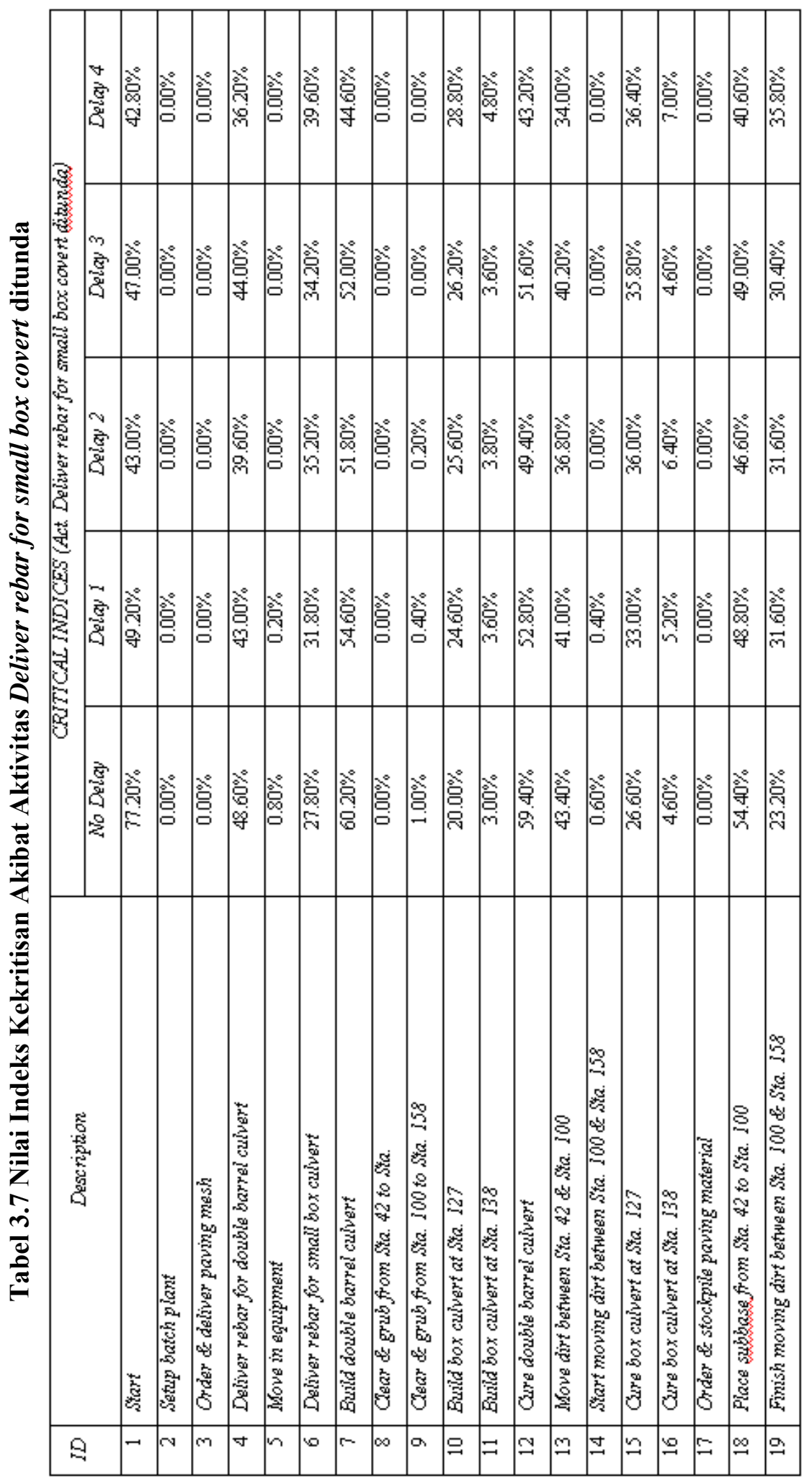

Pengembangan Model Simulasi Integrasi Biaya dan Jadwal Proyek Konstruksi 


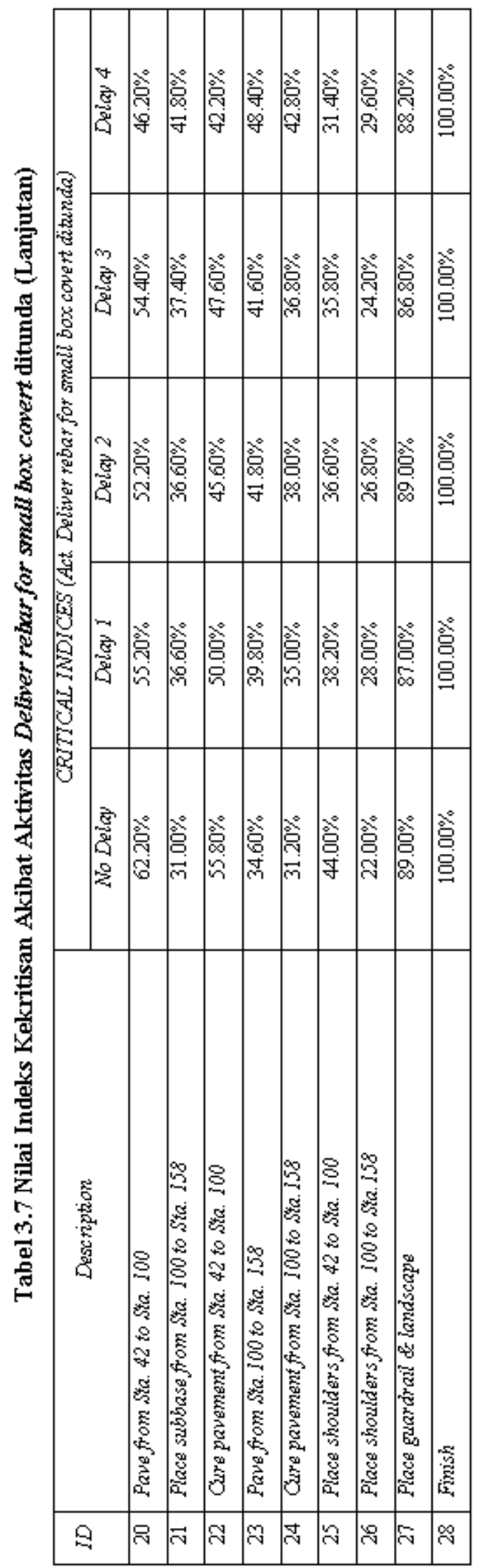




\section{Pemodelan Dampak Penundaan Aktivitas Non Kritis terhadap Durasi Proyek}

Dari hasil simulasi, maka dapat dilihat bagaimana dampak penundaan aktivitas non kritis yaitu deliver rebar for small box covert terhadap purata durasi proyek secara keseluruhan. Hasilnya dapat dilihat pada Tabel 3.7, sedangkan secara grafis diperlihatkan pada Gambar 3.8 dan Gambar 3.9.

Tabel 3.8 Dampak Penundaan Aktivitas deliver rebar for small box covert terhadap Jadwal Proyek

\begin{tabular}{|c|c|c|c|}
\hline Penundaan (hari) & Purata & Std. Deviasi & Prob.( $\leq$ \\
\hline 0 & 63,21 & 6,03 & $80,36 \%$ \\
\hline 1 & 64,22 & 5,66 & $78,11 \%$ \\
\hline 2 & 64,32 & 6,38 & $74,77 \%$ \\
\hline 3 & 64,82 & 6,79 & $73,81 \%$ \\
\hline 4 & 65,26 & 6,74 & $68,47 \%$ \\
\hline
\end{tabular}

\section{Penundaan vs. Purata Durasi Proyek}

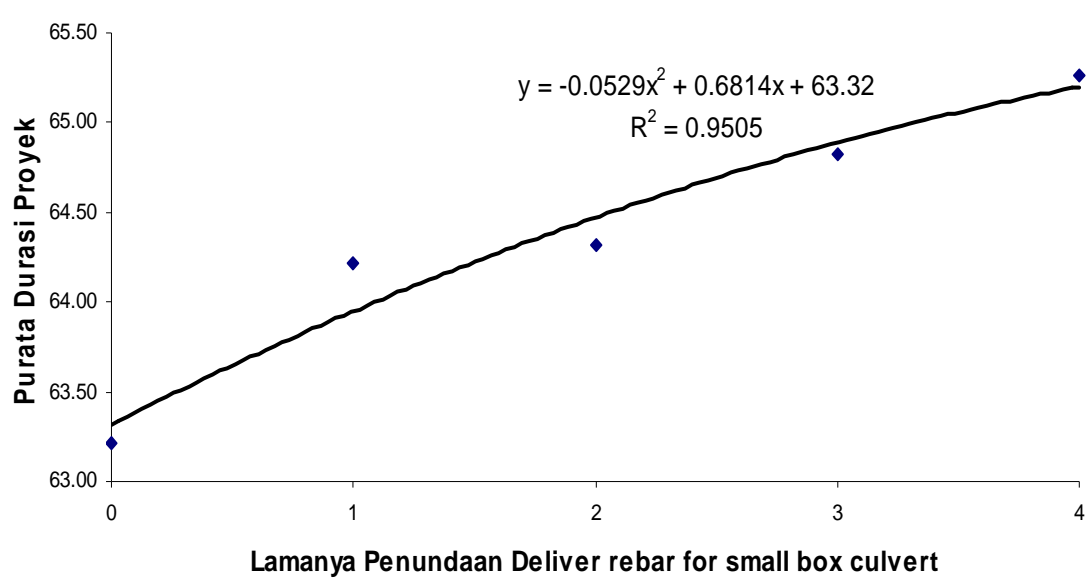

Gambar 3.8 Hubungan Lamanya Penundaan dengan

Purata Durasi Total Proyek

Pada Gambar 3.8 memperlihatkan bagaimana hubungan antara penundaan aktivitas deliver rebar for small box covert dengan purata durasi penyelesaian proyek. Hasil regresi polinomial orde 2 menghasilkan Persamaan 3.5

$$
\mathrm{PS}_{\text {purata }}=-0,0529 \mathrm{FL}_{6}^{2}+0,6814 \mathrm{FL}_{6}+63,32
$$




\section{Di mana $: \mathrm{R}^{2}=0,9505$}

Berdasarkan hasil pensimulasian, dapat dilihat bahwa semakin lama aktivitas pasangan deliver rebar for small box covert ditunda mengakibatkan purata durasi total proyek semakin meningkat. Jika tidak ada penundaan purata durasi total adalah 63,21 hari, sedangkan jika ditunda sampai empat hari maka durasi total meningkat menjadi 65,26 hari. Hal ini disebabkan bertambahnya purata durasi jalur non kritis yang beranggotakan aktivitas deliver rebar for small box covert. Seperti yang diungkapkan oleh Gong dan Rowing (1995), purata durasi total proyek akan meningkat bila purata jalur kritis "mendekati" purata jalur kritis. Peningkatan purata durasi total proyek tidak dapat diimbangi dengan penurunan standard deviasi, hal ini mengakibatkan probabilitas tercapainya proyek sesuai dengan rencana menjadi menurun. Penurunan probabilitas ini harus diantisipasi oleh manajer proyek untuk menghindari proyek menjadi terlambat.

Penundaan aktivitas non kritis berakibat jadwal proyek menjadi kurang fleksibel. Berkurangnya fleksibilitas berarti berkurang juga ketidakpastian. Pada Gambar 3.3 dapat dilihat bahwa dengan bertambah lamanya penundaan aktivitas deliver rebar for small box covert, maka mengakibatkan menurunnya probabilitas proyek diselesaikan sesuai dengan yang direncanakan sebelumnya.

Penundaan vs. Probabilitas $(T<=68)$

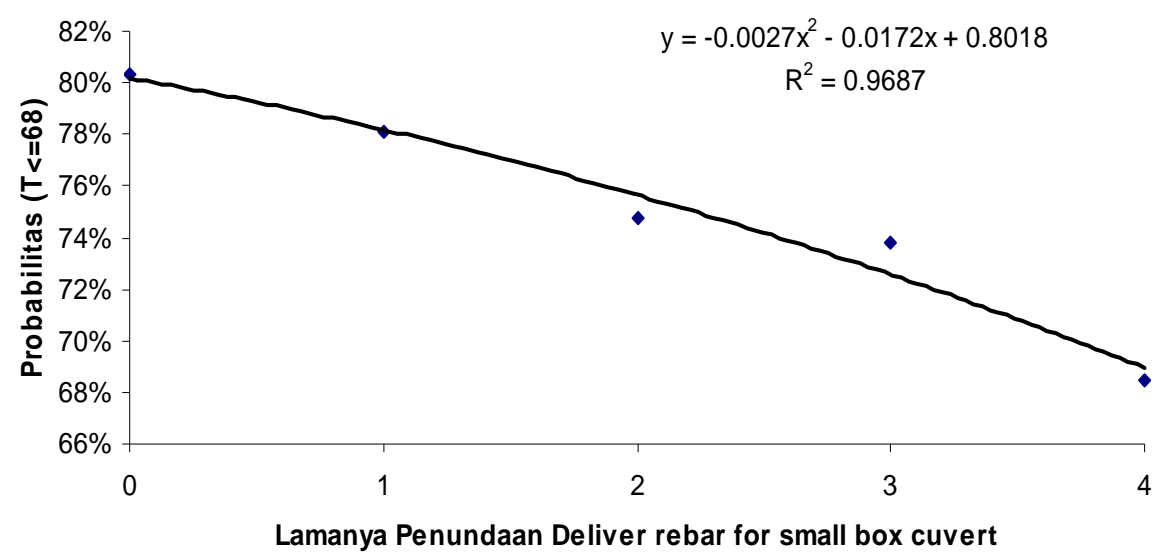

\section{Gambar 3.9 Hubungan Lamanya Penundaan Aktivitas deliver rebar for small box covert dengan Probabilitas Penyelesaian Proyek}

Dari Gambar 3.9 dapat disimpilkan bahwa jika dibatasi waktu penyelesaian proyek selama 68 hari, maka dengan bertambah lamanya penundaan maka berakibat menurunnya probabilitas tercapainya waktu penyelesaian. Dengan demikian maka menunda aktivitas non-kritis meskipun dalam float yang diijinkan tetap berpengaruh 
terhadap waktu penyelesaian proyek. Hal ini harus diwaspadai dalam tahap pelaksanaan dari proyek tersebut.

\section{Pemodelan Dampak Penundaan Aktivitas Non Kritis terhadap Biaya}

Dalam pemodelan dampak penundaan aktivitas non-kritis terhadap biaya, pertimbangan penting adalah bagimana memilih biaya yang secara langsung terhubungan dengan tundaan pada aktivitas deliver rebar for small box covert dengan tingkat keyakinan tinggi. Dengan demikian, ada kemungkinan perubahan yang sangat kecil pada nilai tersebut. Metoda MSAT digunakan untuk memperoleh nilai estimasi total biaya yang terhubung dengan seluruh kehilangan float pada aktivitas deliver rebar for small box covert.

Tabel 3.9 Dampak Penundaan Terhadap Biaya Total dengan

Tingkat Keyakinan Sebesar 0,9

\begin{tabular}{|c|c|}
\hline Penundaan (hari) & Biaya Total \\
\hline 0 & 190,874 \\
\hline 1 & 191,526 \\
\hline 2 & 191,162 \\
\hline 3 & 191,794 \\
\hline 4 & 192,710 \\
\hline
\end{tabular}

Dari hasil pada Tabel 3.9 yang merupakan hasil pensimulasian MSAT, dapat disimpulkan bahwa dengan menunda aktivitas non-kritis menyebabkan semakin meningkatnya biaya total proyek. Hal ini disebabkan dengan semakin lama menunda float aktivitas non kritis, semakin meningkat durasi probabilistiknya, semakin tinggi biaya tidak langsungnya, dan menyebabkan semakin tinggi juga biaya totalnya. Secara grafis dampak penundaan terhadap biaya total dapat dilihat pada Gambar 3.10 


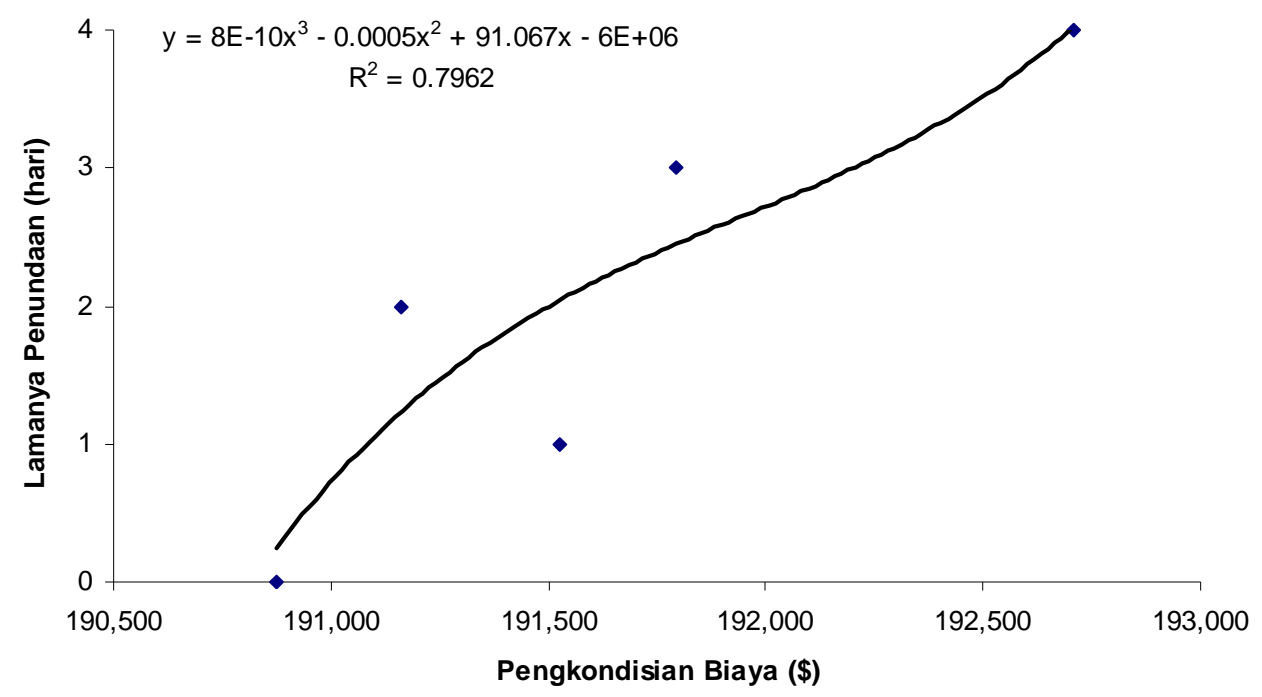

Gambar 3.10 Hubungan Pengkondisian Biaya dengan Lamanya Penundaan

Sakka dan El-Sayegh dalam mengembangkan model dampak biaya menggunakan dataset biaya yang di-generate pada Stage 2. Penggunaan dataset yang di-generate dalam Stage 2 dapat menghasilkan statistik yang melenceng. Durasi yang dihasilkan oleh proses simulasi pada Stage 2 tidak selalu terhubung dengan kehilangan float yang telah ditentukan. Seharusnya pensimulasian jadwal proyek pada jadwal baseline tanpa penundaan adalah dengan menggunakan nilai jadwal yang dihasilkan oleh probabilistik jadwal proyek yang dikondisikan seperti yang dilakukan pada Stage 4.

Perkiraan biaya dapat bergerak secara tidak teratur dari simulasi satu ke simulasi lainnya meskipun pada input dan asumsi yang sama. Dataset dari Stage 4 -lah yang seharusnya digunakan daripada dataset pada Stage 2. Pendekatan inilah yang dilakukan oleh Isidore dan Back (2002) saat menggunakan MSAT untuk menginvestigasi probabilistik biaya dan jadwal.

\section{KESIMPULAN DAN SARAN}

\section{Kesimpulan}

Beberapa kesimpulan yang diperoleh dari penelitian ini adalah sebagai berikut:

1. Secara stokastik, menunda aktivitas non-kritis akan berpengaruh terhadap durasi secara keseluruhan proyek tersebut. Ini dibuktikan dengan menunda aktivitas non-kritis berakibat pada meningkatnya purata dari durasi total dan juga berakibat menurunnya standar deviasinya, ini mengakibatkan menurunnya 
probabilitas tercapainya proyek tersebut sesuai dengan waktu yang telah ditetapkan.

2. Jika risiko ekskalasi biaya dibatasi, mengakibatkan risiko keterlambatan pun menjadi lebih besar dan sebaliknya jika risiko ekskalasi durasi dibatasi pun akan mengakibatkan risiko keterlambatannya semakin besar. Informasi yang diberikan oleh pemodelan ini diharapkan membantu para pelaku dunia konstruksi dalam pengambilan keputusan, dalam hal ini adalah pembatasan biaya maupun durasi terkait dengan risiko keterlambatan.

3. Hasil pensimulasian, menunjukkan bahwa semakin lama aktivitas pasangan deliver rebar for small box covert ditunda mengakibatkan purata durasi total proyek semakin meningkat. Jika tidak ada penundaan purata durasi total adalah 63,21 hari, sedangkan jika ditunda sampai empat hari maka durasi total meningkat menjadi 65,26 hari. Hal ini disebabkan bertambahnya purata durasi jalur non kritis yang beranggotakan aktivitas deliver rebar for small box covert. Seperti yang diungkapkan oleh Gong dan Rowing (1995), purata durasi total proyek akan meningkat bila purata jalur kritis "mendekati" purata jalur kritis. Peningkatan purata durasi total proyek tidak dapat diimbangi dengan penurunan standard deviasi, hal ini mengakibatkan probabilitas tercapainya proyek sesuai dengan rencana menjadi menurun. Penurunan probabilitas ini harus diantisipasi oleh manajer proyek untuk menghindari proyek menjadi terlambat. Penundaan aktivitas non kritis berakibat jadwal proyek menjadi kurang fleksibel. Berkurangnya fleksibilitas berarti berkurang juga ketidakpastian. Pada Gambar 3.3 dapat dilihat bahwa dengan bertambah lamanya penundaan aktivitas deliver rebar for small box covert, maka mengakibatkan menurunnya probabilitas proyek diselesaikan sesuai dengan yang direncanakan sebelumnya.

4. Berdasarkan hasil pada Gambar 3.4 maka dapat disimpulkan bahwa dengan menunda aktivitas non-kritis menyebabkan semakin meningkatnya biaya total proyek. Hal ini disebabkan semakin lama menunda float aktivitas non kritis, semakin meningkat durasi probabilistiknya, semakin tinggi biaya tidak langsungnya, dan menyebabkan semakin tinggi juga biaya totalnya.

\section{Saran}

Berdasarkan penelitian yang telah dilakukan, ada beberapa saran yang perlu untuk dilakukan pada penelitian berikutnya antara lain: 
1. Diperlukan penyempurnaan piranti yang digunakan, dalam hal ini diperlukan pemrograman yang "user friendly" untuk memodelkan penjadualan yang terintegrasi dengan biaya.

2. Pada tulisan ini terbatas hanya untuk jaringan kerja secara CPM di mana hubungan antar aktivitas bersifat finish to start (FS constrain), sedangkan pada proyek riil tidaklah demikian. Untuk itu maka dibutuhkan penyempurnaan dalam pemrograman yang dilakukan dalam pemodelan ini.

\section{DAFTAR PUSTAKA}

1. Ang, A.H-S dan Tang. (1994). Probability Concept in Planning and Controlling Construction Projects, $2^{\text {nd }}$. Ed. John Wiley\&Sons, New York.

2. Ahuja, H.N. et al. (1994). Project Management: Techniques in Planning and Co ntrolling Construction Projects, $2^{\text {nd }}$. Ed., John Wiley\&Sons, New York.

3. Cox, M.A.A. (1995). "Simple Normal Approximation to the Completion Time Distribution for a PERT Network", International J. Project Mgmt., Vol 13. No.4.265-270.

4. Gong, D. dan Rowings Jr, J.E. (1995). "Calculation of Safe Float Use in Risk Analysis Oriented Network Scheduling”, Internaional J. Project Mgmt., Vol 13. No.3.187-194.

5. Isidore, L.J dan Back, W.E (2002)."Multiple Simulation Analysis for Probabilistic Cost and Schedule Integration", J. Constr. Eng. Mgmt. Vol 128. No.3.211-219.

6. Palisade Corporation (2001). Guide to Using @Risk. New York.

7. Sakka, Z.L. dan El-Sayegh, S.M.(2007).'Float Consumption Impact on Cost and Schedule in Connstruction Industry". J. Constr. Eng. Mgmt. Vol. 133.No.2.124130

8. Wibowo, Andreas. "Apakah Pendekatan Simulasi Lebih Baik Dibandingkan Pendekatan Analitis? Kasus: Dampak Konsumsi Float Aktivitas Nonkritis"

9. Wibowo, Andreas. "Float Consumption Impact on Cost and Schedule in Connstruction Industry Discussion by: Andreas Wibowo", J. Constr. Eng. Mgmt.

10. Wicaksono, Yudhy. Membuat Fungsi dan Program Bantu Microsoft Excel, Penerbit PT. Elex Media Komputindo, Jakarta, 2007.

11. http://www.civil.uwaterloo.ca/tarek/hegazyfre1.html tanggal akses: 12 Oktober 2007. 